\title{
Sveti Marko Evanđelist u kršćanskoj kulturnoj baštini Hrvata
}

\author{
Marko Dragić* \\ mdragic@ffst.hr
}

UDK: 235.3 Marcus Evangelista, sanctus

$39: 23 / 28(=163.42)$

Pregledni članak / Review

Primljeno: 20. veljače 2016. Prihvaćeno: 4. lipnja 2016.

Sveti Marko Evandelist (Cirena, oko 10. - Aleksandrija, 25. travnja 68.) bio je od židovskoga roda levita. Štuju ga: Rimokatolička crkva, Pravoslavna crkva, Koptska crkva, istočne katoličke crkve, Luteranska crkva. Višestruki je zaštitnik. Štovanje sv. Marka Evanđelista u kršćanskoj tradicijskoj kulturi Hrvata ogleda se u: legendama; katedralama i crkvama posvećenim tomu evandelistu; toponimima; krematonimima; procesijama i blagoslovima polja, usjeva, vinograda; pučkim veseljima (kirbajima, dernecima); pomaganju sirotinji; kultnim svetištima; pučkim divinacijama i izrekama; krjesovima; usmenim lirskim pjesmama; molitvama. U radu se navode rezultati terenskoga istraživačkog rada koji se odvijao od 1997. do 2016. godine. Na terenu u Hrvatskoj, Bosni i Hercegovini, Crnoj Gori i Srbiji u Hrvata katolika izvorno je zapisano pedesetak legendi, molitvi, običaja, obreda, ophoda, divinacija. Na temelju Novoga zavjeta te predaja i legendi (re)konstruira se život sv. Marka Evandelista. Pored toga, cilj rada je i od zaborava sačuvati starinske legende, običaje, obrede, ophode, usmene lirske pjesme, molitve, divinacije, te multidisciplinarnom interpretacijom ukazati na njihovu socijalnu i estetsku funkciju. Pored terensko-istraživačkoga rada primjenjuje se induktivno-deduktivna metoda, te metode: deskripcije, komparacije, analize i sinteze.

Ključne riječi: legende, običaji, procesije, divinacije, usmene lirske pjesme.

Ni u čem se tako jasno ne zrcali duša nekoga naroda, kao što u njegovim običajima, koji posvjedočuju njegovu veću ili manju uljudbu i jamče za veći ili manji mu napredak u budućnosti. (...) Kao što nijedan narod, tako nije niti naš bez običaja, uz koje se drži čvrsto i ozbiljno kao uz vjerske čine, ukratko, kao uz kakove svetinje, pak ne trpi da mu itko u njih dira. Antun Ilija Carić, 1896.

\footnotetext{
* Prof. dr. sc. Marko Dragić, predstojnik Katedre za književnost i kulturu Filozofskoga fakulteta Sveučilišta u Splitu, Sinjska 2, HR-21000 Split.
} 


\section{Uvod}

Sv. Marko Evanđelist u kršćanskoj kulturnoj baštini Hrvata nedostatno je istražen. Dokaz tomu je i to što se sv. Marko uopće ne spominje u monografijama. Tako nije spomenut u monografiji Luke Ilića Oriovčanin Narodni slavonski običaji, Zagreb, 1846. Zanimljivo je da ponajveći hrvatski etnolog Milovan Gavazzi u svojoj kultnoj monografiji Godina dana hrvatskih narodnih običaja, 1939., ne spominje blagdan sv. Marka, tim više što Mijat Stojanović navodi nekoliko običaja vezanih uz Markovo u svome djelu Slike iz domaćega života slavonskog naroda $i$ iz prirode, s dodatkom Slavonske pučke sigre, Zemun, 1858., koje je publicirano 87 godine prije Gavazzijeva djela. Po tri-četiri rečenice o blagdanu sv. Marka u svojim djelima navode: Frano Ivanišević (1906.), Silvestar Kutleša (1938., a djelo je objavljeno tek 55 godina kasnije - 1993.), Ljubo Mićević (uoči Drugoga svjetskog rata, a rad je objavljen 1952.) i Jerko Suton (1968.).

Stoga se u ovom radu navode rezultati terenskoga istraživačkog rada koji se odvijao od 1997. do 2016. godine. U Hrvatskoj, Bosni i Hercegovini, Crnoj Gori i Srbiji u Hrvata katolika izvorno je zapisano pedesetak legendi, običaja, obreda, ophoda, divinacija, izreka, usmenih lirskih pjesama, molitvi. ${ }^{1}$ Običaji, obredi, ophodi i divinacije u radu se interpretiraju u etnološkom i antropološkom kontekstu. Komparativno se navode i neki običaji Srba pravoslavaca.

U radu se rekogniscira kult sv. Marka Evanđelista u kršćanskoj kulturnoj baštini Hrvata. Pored toga, cilj rada je i od zaborava sačuvati starinske legende, običaje, obrede, ophode, usmene lirske pjesme, molitve, divinacije, te multidisciplinarnom interpretacijom ukazati na njihovu socijalnu i estetsku funkciju.

\section{Legende o sv. Marku Evandelistu}

Legenda je riječ latinskoga podrijetla i znači - ono što treba čitati. U književno-teorijskom pogledu legenda je vrsta usmene priče koja ima vjerski karakter. U njezin se sadržaj vjeruje. U legendama su sudionici Isus Krist, mučenice i mučenici, sveci, svetice, crkveni dostojanstvenici. Legenda se dugo poimala kao pripovijest iz života svetaca te o Božjim i svetačkim čudesima. Legende su fakturom bliske predaji i katkad su teško odvojive od njih, ali je ipak element čuda u legendama njihov genus specificum što ih donekle izdvaja od predaja.

\footnotetext{
${ }^{1}$ U radu se navode: FF ST - Filozofski fakultet Sveučilišta u Splitu; FF MO - Filozofski fakultet Sveučilišta u Mostaru; Vl. rkp. zb. - Vlastita rukopisna zbirka. Te su rukopisne zbirke nastale kao rezultat autorovih izvornih terenskih zapisa kao i zapisa studenata filozofskih fakulteta u Splitu i Mostaru kojima je autor rada bio mentorom pri izradi seminarskih, završnih i diplomskih radova iz kolegija: Hrvatska usmena književnost, Hrvatska tradicijska kultura u europskom kontekstu i Povijesne predaje (D - diplomski rad, Z - završni rad, S - seminarski rad).
} 
O životu starokršćanskih mučenica i mučenika iznimno je malo pouzdanih podataka. Međutim, oko života starokršćanskih mučenica i mučenika kroz dva tisućljeća narod je ispleo mnoge predaje i legende. U tom smislu paradigmatsko je djelo »Legenda aurea« Jakoba Voraginskoga.

\section{1. Život}

Marko Evanđelist (Cirena, oko 10. - Aleksandrija, 25. travnja 68.) ${ }^{2}$ bio je od židovskoga roda levita. ${ }^{3}$ Rođenjem je dobio ime Ivan, a kasnije se prozvao Marko. Kršteni kum bio mu je sv. Petar apostol te je Marko s njim otišao u Rim gdje je bio Petrov tajnik i tumač grčkoga jezika. Ondje je zapisivao propovijedi sv. Petra koji je pregledao zapisane propovijedi i uvjerio se da su istinite te je zapovjedio da ih treba čitati u Rimu. Tako je nastalo evanđelje za koje bibličari smatraju da je napisano prvo od svih kanonskih evanđelja. Markovo evanđelje posebno ističe Kristovo čovještvo.

Sv. Petar je gledao Marka postojanoga u vjeri te ga je poslao u Akvileju da ondje propovijeda vjeru Isusa Krista i ljude obraća. U Akvileji je, kao i u Rimu pisao svoje evanđelje. Nakon toga sv. Marko je sretan u Rim poveo poglavara Akvileje, Ermagorasa s kojim je otišao do sv. Petra moleći ga da Ermagoras bude biskup Akvileje. Sv. Petar je zaredio Ermagorasa biskupom Akvileje. Ermagoras je upravljao mnogim crkvama te je podnio mučeništvo. ${ }^{4}$

Dok je sv. Marko propovijedao po Jadranu, zahvatila ga je snažna oluja i natjerala među otočiće i sprudove. Tada mu se ukazao anđeo i rekao: »Na ovim lagunama izrast će velik grad tebi na čast!« Četiri stotine godina kasnije ljudi su, bježeći od Atiline vojske, sklonili se na te otoke i, prema tradiciji, 421. godine utemeljili grad Veneciju. Sv. Marko je dvanaest godina u Libiji propovijedao Evanđelje. ${ }^{5}$ Sa svojim ujakom Barnabom ${ }^{6}$ i sa sv. Pavlom putovao je od Jeru-

\footnotetext{
${ }^{2}$ Sveti Marko Evanđelist (07.05.2013) www.zupa-rovisce.com/hr/index.php/duhovnost/227sveti-marko-evandelist (14.02.2016).

${ }^{3}$ Leviti su potomci jednoga od dvanaestoro Jakovljeve djece iz Staroga zavjeta. Nakon povratka iz pustinje u Izrael dobili su zadatak čuvati hram u Jeruzalemu.

${ }^{4}$ Jakob Voragina, Medieval Sourcebook. The Golden Legend, III. (09.2000) www.fordham.edu/ halsall/basis/goldenlegend/GoldenLegend-Volume6.asp (14.02.2016).

${ }^{5}$ Anđelko BADURINA (ur.), Leksikon ikonografije, liturgike $i$ simbolike zapadnog kršćanstva i Uvod u ikonologiju Radovana Ivančevića, Zagreb, Kršćanska sadašnjost, 1990, 395-396.

${ }^{6}$ Barnaba je odmah po Kristovoj smrti prihvatio kršćanstvo. U kršćansku zajednicu prihvatio je Savla (Pavla) jer ga drugi apostoli nisu prihvatili sumnjajući u njegove namjere. S Pavlom je »probijao granice judaizma«. Zalagao se za univerzalno kršćanstvo. Nakon razlaza s Pavlom kršćanstvo je širio u helenističkim krugovima. Bio je iznimnoga stasa zbog čega su ga nakon čudesa proglasili Jupiterom. Smatra se da je kamenovan koncem 1. stoljeća. Relikvije su mu s autografom Matejeva evanđelja na prsima pronađene 488. godine na Salamini. Prema predajama od toga se evanđelja nije nikada odvajao. U ikonografiji se prikazuje kako pripovijeda u Listri i kako mu se klanjaju kao Jupiteru ili kako s knjigom evanđelja ozdravlja bolesne. Atributi su mu: Matejevo evanđelje, kamen, koplje i bradva (usp. Badurina, nav. dj., 138-139).
} 
zalema u Antiohiju.7 Oko 50. godine pratio je Barnabu na njegovu putovanju na Cipar. Barnaba i Marko otišli su na Cipar. Pavao je sebi uzeo Silu i nastavio širiti kršćanstvo po Siriji i Ciliciji. ${ }^{8} \mathrm{Za}$ vrijeme prvoga Pavlova zatočeništva ${ }^{9} \mathrm{u}$ Rimu oko 60. godine, pripremajući se za svoje putovanje u Malu Aziju, Marko je susreo Pavla. Izašavši iz tamnice Pavao i Sila otišli su Lidiji ${ }^{10} u$ Filipe gdje su braću ohrabrili i otišli. Potom je Pavao ${ }^{11}$ oko 65. godine poslao Marka u Aleksandriju gdje je bio biskupom. Prema legendi Jakova Voraginskoga, sv. Marko je na putovanju poderao cipelu te je otišao postolaru kojemu je za sebe rekao da je sluga Isusa Krista. Postolar je iskazao veliku želju vidjeti Isusa. Tada je sv. Marko počeo propovijedati vjeru u Isusa Krista i mnoge je obratio na kršćanstvo. U Aleksandriji je sv. Marko naišao na veliko neprijateljstvo.

\subsection{Mučeništvo}

Kad je toga dana sv. Marko odslužio misu, pogani su se skupili, vezali ga oko vrata i izvukli iz crkve i po cijelom gradu vukli. Dio njegova tijela ostao je na putu. Nakon toga stavili su ga u zatvor gdje ga je došao tješiti anđeo. Ukazao mu se i Gospodin tješeći ga riječima: »Pax tibi, Marce, evangelista meus. - Mir tebi, Marko, evanđelistu moj, ne budi u nedoumici, jer ja sam s tobom i oslobodit ću te!« Ujutro su pogani uzeli konopac svezali ga sv. Marku oko vrata i izvukli ga iz zatvora. Marko je rekao: »U tvoje ruke, Gospodine, predajem duh svoj!« Tako govoreći je umro. Pogani su htjeli spaliti svečevo tijelo. Međutim, vrijeme se naglo promijenilo; počela je silna grmljavina i sijevanje te su pogani

7 Svetac dana - sv. Marko http://zupajastrebarsko.hr/svetac_dana.asp?mjesec $=4 \&$ dan $=25$ (14.02.2016).

${ }^{8}$ Cilicija (Kilikija) je starovjekovna regija koja se nalazila na granici Male Azije sa Sirijom, sjeverno od Cipra, u današnjoj Turskoj.

${ }^{9}$ Cijeli je događaj opisan u Dj 16, 16-40: Nekoliko dana za Pavlom i Silom išla je vračara i govorila: »Ovi su ljudi sluge Boga Svevišnjega; navješćuju vam put spasenja « (Dj 16, 17). Pavlu je to dodijalo pa se okrenuo i zapovjedio nečastivom da izađe iz vračare. Nakon toga vračara nije mogla zarađivati svojim gospodarima pa su uhvatili Pavla i Silu i odveli ih na trg pred poglavare optuživši ih da uznemiruju njihov grad. Svjetina je navalila na Pavla i Silu, pretori su strgali s njih odjeću i zapovjedili da ih išibaju te utamniče, a noge im stave u okove. Pavao i Sila su oko ponoći pjevali hvalu Bogu, a uznici su ih slušali. Odjednom je nastao velik potres. Temelji zatvora su se zaljuljali, vrata otvorila, a uznicima popadali okovi. Tamničar se bio trznuo iz sna te je, vidjevši otvorena vrata tamnice, mislio da su zatvorenici pobjegli. Trgnuo je mač i zbog toga se htio ubiti. »Ali Pavao povika iza glasa: 'Ne čini sebi nikakva zla! Svi smo ovdje!' Onaj nato zaiska svjetlo, uleti i dršćući baci se pred Pavla i Silu; izvede ih i upita: 'Gospodo, što mi je činiti da se spasim?' Oni će mu: 'Vjeruj u Gospodina Isusa i spasit ćeš se - ti i dom tvoj!’ «(Dj 16, 28-31). Tamničar im je odmah oprao rane te se krstio kao i svi u njegovu domu.

${ }^{10}$ Lidija je bila trgovkinja grimizom ili proizvodima obojenim tom bojom. Živjela je u Filipima, glavnom gradu Makedonije. Podrijetlom je bila iz Tijatire u Maloj Aziji. Pavao je s Lukom, Silom i Timotejem na Balkanu počeo propovijedati oko 50. godine. Lidija je prva krštena Europljanka. Kršteni su i svi članovi njezina doma. Sačuvano je mjesto gdje je Pavao krstio Lidiju i tamošnji potok naziva se Lidija.

${ }^{11}$ Jakov Voraginski piše da ga je poslao sv. Petar. 
pobjegli ostavivši sveto tijelo. Tada su došli kršćani i, uz veliko štovanje, tijelo pokopali. ${ }^{12}$ Bilo je to 25 . travnja 68 . godine, za vrijeme vladanja cara Nerona.

U Novom zavjetu Ivan zvani Marko spominje se osam puta, a deveti put se spominje njegova majka Marija. U Marijinu domu okupljala se prva jeruzalemska kršćanska zajednica. ${ }^{13}$ Po nekim izvorima Isus je posljednju večeru blagovao u kući Markove majke Marije. ${ }^{14}$

\subsection{Relikvije}

U vrijeme cara Lava, 466. godine, dva su mletačka trgovca - molbama i darovima dvojici svećenika koji su čuvali svečev grob -, uspjela izvaditi njegovo tijelo iz groba. Tada se miomiris osjetio po cijeloj Aleksandriji. Tijelo sv. Marka stavili su u brod i krenuli prema Veneciji. Međutim, odmah je nastao mrak gust kao vosak i nisu mogli otploviti prema Veneciji. Tada se sv. Marko ukazao onoj dvojici svećenika koji su čuvali njegov grob i rekao im da požure do Mlečana i vrate njegovo tijelo. Jedan Egipćanin je relikvije sakrio u mramorni stup. Kad je on umro nitko nije znao gdje se nalaze relikvije i nastupila je velika žalost i plač. Svećenici su predvodili procesije, moleći litanije. Vjernici su postili i molili. Odjednom se stup rastvorio i pokazalo se svečevo tijelo. Tada je odlučeno da će se vječno na taj dan održavati svečanosti. ${ }^{15}$ Mletački su trgovci relikvije sv. Marka 828. godine iz Aleksandrije prenijeli u Veneciju te su najprije pokopane u duždevoj kapeli. Od tada je sveti Marko zaštitnik Venecije, a njegov simbol usvojen je kao grb grada. U Veneciji je između 1063. i 1073. godine sagrađena katedrala sv. Marka.

\section{2. Čuda po zagovoru sv. Marka Evandelista}

Jakov Voraginski navodi više čuda koja su se dogodila po zagovoru sv. Marka Evanđelista:

Neki je mladić bolovao od raka pluća. U snu mu se ukazao sv. Marko tražeći od njega da odmah krenu preko mora spasiti brod koji je bio u opasnosti. Položio je ruku na mladića i otišao. Kada se mladić probudio bio je potpuno zdrav. Sv. je Marko spasio brod s mornarima koji su sretno došli u Veneciju.

Kad su trgovci u jednom saracenskom brodu otišli na put iz Venecije, našli su se u opasnosti. Brod se počeo raspadati i svi su Saraceni popadali u more

\footnotetext{
${ }^{12}$ Usp. Jakob Voragina, Medieval Sourcebook...

${ }^{13}$ Usp. Antun JARM, Imena $i$ imendani, Obiteljski imenar, Zadar, Hrvatski institut za liturgijski pastoral, 1996, 83.

${ }^{14}$ Usp. Sveti Marko (25.04.) www.tolisa.info/index.php?option=com_content\&task=view\&id=46 8\&Itemid=1 (17.01.2016).

${ }^{15}$ Jakob Voragina, nav. $d j$.
} 
i umrli. Jedan od njih po imenu Anon obećao je sv. Marku da će se pokrstiti ako bude spašen iz te pogibelji. Svetac ga je izvadio iz mora i odmah je oluja prestala. Kad se vratio u Aleksandriju Anon nije ispunio obećanje. Ukazao mu se sv. Marko i Anon je otišao u Veneciju, krstio se, uzeo ime Marko i bio savršen vjernik. Umro je učinivši mnoga dobra djela.

Neki je čovjek padao sa zvonika sv. Marka u Veneciji. U pomoć je zazvao sv. Marka i bio je odmah spašen. Zbog toga je sv. Marko zaštitnik zidara.

Gospodar Provanse imao je slugu koji je pošao na hodočašće sv. Marku. To ga je naljutilo te je slugu izvrgnuo raznim mukama. Zapovjedio je da sluzi izvade oči, ali izvršitelji nisu uspjeli. Tada je zapovjedio da tome sluzi sjekirama sijeku bedra, ali su sjekire postale meke kao rastopljeno olovo. Potom je zapovjedio da mu čekićima polome zube, ali su čekići postali mekani. Vidjevši čuda gospodar je otišao u Veneciju moleći oprost od sv. Marka i uzeo ga za svoga zaštitnika.

Neki je vitez u borbi bio teško ranjen tako da mu je ruka visila. Liječnici su smatrali da ruku moraju amputirati. Vitez se preporučio sv. Marku i odmah mu je ruka zacijelila. Prema drugoj legendi neki vitez je naoružan na konju išao mostom preko rijeke. I on i konj pali su u vodu. Preporučio se sv. Marku i bio je spašen. Otišao je u Veneciju i ondje pripovijedao o čudu koje je doživio.

Nekoga su čovjeka iz zavisti mrzili i utamničili ga četrdeset dana. Teško ožalošćen preporučio se sv. Marku koji mu se tri puta ukazao i oslobodio ga iz uzništva. Sretan što je čudesno oslobođen otišao je u crkvu sv. Marka zahvaliti Bogu.

U Apuliji je vladala velika glad jer ništa nije uspijevalo rasti na njihovoj zemlji. Počeli su štovati sv. Marka i zemlja je postala vrlo plodna.

Godine 1241. neki je fratar bio na samrtnoj postelji. Pogledao je prema nebu i zavapio: »Gospodine Bože, uzmi moju dušu iz ovog zatvora«; a nakon što je rekao: »Jao! Tko će me istrgnuti iz ovoga grješnoga i smrtnog tijela?«, utonuo je u san i vidio sv. Marka kako stoji kod njegova kreveta. Uskoro je fratar s velikom radošću preminuo. ${ }^{16}$

\section{Višestruki zaštitnik}

Svetoga Marka Evanđelista štuju: Rimokatolička crkva, Pravoslavna crkva, Koptska crkva, istočne katoličke crkve, Luteranska crkva. Zaštitnik je: odvjetnika, građevinskih radnika, zidara, staklara, pletača košara, notara, pisara, zatvorenika, zarobljenika, vitražista, staklara, lavova, Venecije, Egipta. Njemu se utječe protiv nevremena, munje, tuče, protiv nepripravne smrti te za dobro vrijeme i dobru žetvu. Zaziva ga se u slučajevima okorjelosti, nekajanja, uboda kukaca, gušavosti, bolesti i izraslina na vratu.

\footnotetext{
${ }^{16}$ Sva čuda navode se prema Jakob Voragina, nav. $d j$.
} 


\subsection{Katedrale i crkve sv. Marka Evandelista u Hrvata}

Zaštitnik je mnogih biskupija, naselja, župa i crkava diljem Hrvatske i svijeta. Katedrale u Korčuli i Makarskoj posvećene su sv. Marku.

Među crkvama posvećenim sv. Marku posebno mjesto zauzima drevna crkva sv. Marka u Zagrebu, na Griču. Župa sv. Marka osnovana je 1261. godine, a crkva se prvi put spominje 1256. godine ${ }^{17}$ Ta je crkva simbol Gornjega grada i ušla je u brojna sudbonosna zbivanja hrvatskoga naroda. Zaštićeno je kulturno dobro Republike Hrvatske.

U Jakuševcu je 1832. godine sagrađena drvena crkva sv. Marka Evanđelista. Na tome mjestu bila je stara župna crkva sv. Marka koja je 1811. ondje preseljena s posjeda Erdödyjevih u Trnju. Ta crkva je među prvim poslijebaroknim drvenim crkvama nastalim na području Turopolja. Inventar crkve jest golemo bogatstvo. Crkva je zaštićeno kulturno dobro. ${ }^{18}$

Pored tih crkava, u Republici Hrvatskoj i Bosni i Hercegovini među katoličkim župama posvećenim sv. Marku Evanđelistu jesu: Topolje kod Draža, Našice, Markovac Našički, Slobodnica kod Sibinja, Trnjani kod Garčina, Sigetec kod Peteranca, Vinica, Selnica, Kašćerga kod Pazina, Markovac kod Višnjana, Veprinac kod Opatije, Valun na Cresu, Orah kod Vrgorca, Split - Neslanovac, Gornje Podbablje, Crivac kod Muća, Potočani kod Odžaka, Plehan kod Dervente, Tolisa kod Orašja, Ilijaš, Gradačac, Klobuk kod Ljubuškog, Mostar - Cim. ${ }^{19}$ Gradnju crkve sv. Marka u Gornjem Vinovu kod Unešića narod je obavio koprenom legende:

»Sad di je naša crkva, tu ti je prije u stara doba bila kapelica sv. Jelene. Tili su seljani gradit crkvu bliže selu, u centru, ode doli na Kosi. Tako bi ti oni obdan kresali kamen, ostavljali ga na Kosi, a po noći bi neko kamen prinija gori di je sad crkva. Sve šta bi bilo okresano za dana, sve bi po noći ošlo gori. I tako jedan dan, pa drugi (...) tako nekoliko dana zaredon i onda su ljudi stavili stražu, da vide ko nosi, ma ni onda nisu saznali šta je bilo, jer bi svake noći taj ko je čuva, zaspa, ne bi ga moga čovik probudit. Najzad su graditelji počeli sami nosit gori građu i tako ti je sad gori naša crkva.«²0

Katolička crkva Hrvata, posvećena sv. Marku u bačkom selu Žedniku (u Vojvodini) građena je od 1910. do 1912. godine. U središtu mjesta Štoj kod Ulcinja u Crnoj Gori 2006. godine sagrađena je prelijepa crkva posvećena sv. Marku. Tijekom ljeta u toj se crkvi služi misa na nekoliko jezika.

\footnotetext{
${ }^{17}$ www.putovnica.net/odredista/hrvatska/zagreb/sto-posjetiti-znamenitosti-u-zagrebu/crkvasv-marka (14.02.2016).

${ }^{18}$ Crkva sv. Marka Evanđeliste (12.10.2014) https://hrhr.facebook.com/svjedocanstva/posts/814429621912203 (14.02.2016).

${ }^{19}$ Župa sv. Nikole biskupa, Jastrebarsko, sv. Marko, 25. travanj http://zupajastrebarsko.hr/svetac. asp?id=252 (13.02.2016).

${ }^{20}$ Ana Ivić zapisala 2011. godine, a kazao joj je Ante Ivić u Vinovu Gornjem (FF MO, 2011, D).
} 
Fra Petar Bakula u svojem Šematizmu 1867. godine napisao je da su na području Hercegovačke franjevačke provincije do turske okupacije postojale ove crkve posvećene sv. Marku Evanđelistu: u Vrpolju kod Rakitna, iznad Grabovice kod Livna, u Dragićini kod Gruda. ${ }^{21}$ Između zapada i sjevera Županjca (današnjega Tomislavgrada) leže velike ruševine crkve pod imenom sv. Marka, gdje se svake godine na Markovdan blagoslivljalo polje. ${ }^{22}$

Blagdan sv. Marka u Rimokatoličkoj crkvi je 25. travnja, a istoga ga datuma slave i pravoslavne crkve (ako koriste julijanski kalendar, onda je to 8. svibnja po gregorijanskom kalendaru).

U ikonografiji se uz sv. Marka najčešće prikazuje krilati lav što jedni tumače da taj motiv predstavlja »kraljevsko dostojanstvo Isusa Krista, lava iz koljena Judina ${ }^{23}$ Drugi sliku s lavom tumače kao prikazivanje čovještva Isusa Krista. Treći tumače da krilati lav simbolizira snagu uskrsnuća i savladavanja smrti. Na slikama se sv. Marko prikazuje i s perom i knjigom Evanđelja.

\subsection{Trebinjsko-mrkanska biskupija}

Između Dubrovnika i Cavtata nalazi se otok Mrkan (Markan). Taj otok ime baštini po sv. Marku evanđelistu. Trebinjska biskupija spominje se za vrijeme pontifikata pape Grgura V. (996.-999.) i jedna je od najstarijih biskupija koje su uspostavljene dolaskom Hrvata i njihovim pokrštavanjem. Od 1000. do 1250. sjedište biskupije bilo je u Trebinju. Katedrala je bila posvećena sv. Mihovilu arkanđelu.

Tatari su trebinjski kraj opustošili od 1240. do 1242. godine. Raški kralj Uroš I. je 1252. godine protjerao trebinjskoga biskupa Slavija koji je 1284. od dubrovačke plemićke obitelji Theophilis u posjed dobio tri otočića: Mrkan (sv. Marko), ${ }^{24}$ Bobara (sv. Barbara), ${ }^{25}$ Supetar (sv. Petar) ${ }^{26}$ Od Gradskoga vijeća Dubrovnika primio je poluotok Molunat. ${ }^{27} \mathrm{Na}$ otoku sv. Marka 1218. spominje se benediktinski samostan. Posljednji dominikanac spominje se 1296. na otoku Lokrumu, a ne na otoku sv. Marka. Papa Martin IV. naložio je dubrovačkom nadbiskupu Bonaventuri da providi biskupske katedre u Trebinju i Stonu. Mrkanski biskup, fra Nikola spominje se 1322. godine, a 1326. kao trebinjski biskup administrira na Mrkanu.

\footnotetext{
${ }^{21}$ Prijevod Bakulinog Šematizma sačinio je dr. Vencel Kosir, a objavilo ga je Vijeće za znanost Hercegovačke franjevačke provincije u Mostaru koncem 1970., pod naslovom »Hercegovina prije 100 godina ili topografsko-historijski šematizam Franjevačke kustodije i apostolskog vikarijata u Hercegovini za godinu Gospodnju 1867.«.

${ }^{22}$ Marko DRAGIĆ, Zakopano zvono, Baška Voda, Mala nakladna kuća Sveti Jure, 1996, 24.

${ }^{23}$ Badurina, nav. dj., 396.

${ }^{24}$ Otok je danas nenastanjen.

${ }^{25}$ Otok je danas nenastanjen.

${ }^{26} \mathrm{Na}$ otočiću danas živi nekoliko obitelji.

${ }^{27}$ Poluotok je nastanjen.
} 
Papa Klement VI. 1344. trebinjsko-mrkanskoga biskupa Bonifacija premjestio je u Šibenik. Od te godine sve više je u uporabi bio naslov mrkanski biskup. U 14. st. Sveta Stolica trebinjske biskupe imenovala je naslovnima, a rezidirali su u više europskih gradova. Od 1391. do 1819. godine Trebinjsko-mrkanska biskupija imala je svoje biskupe koji su boravili na dubrovačkom području.

Papa Leon XIII. apostolskim pismom »Ex hac augusta« 5. srpnja 1881. uspostavio je metropolitansko sjedište u Sarajevu s Vrhbosanskom nadbiskupijom sa sjedištem u Sarajevu; Banjolučkom biskupijom sa sjedištem u Banjoj Luci te Mostarsko-duvanjskom biskupijom sa sjedištem u Mostaru. Metropoliji pripada i Trebinjsko-mrkanska biskupija koja obuhvaća Trebinje, Stolac, Bileću, Nevesinje i Gacko. Apostolski upravitelj trebinjsko-mrkanski je mostarsko-duvanjski biskup.

\section{Procesije, blagoslov polja}

Na blagdan sv. Marka Evanđelista održava se prvi blagoslov polja. Nekoć je blagoslov polja okupljao mnoštvo vjernika i bio je iznimno važan za naše pretke. Barem bi jedna osoba iz svake obitelji sudjelovala u tom obredu. Blagoslov polja 25. travnja odgađao se samo ako je toga dana Uskrs, onda se blagoslov obavljao na drugi dan Uskrsa.

Nekoć se u procesijama odvijao blagoslov polja. Procesija je vjerska povorka koja ide s jednoga na drugo mjesto ili se obilazeći vraća polazno mjesto. U procesiji se uvijek nosi neka sakralna stvar ili znak. U kršćanstvu se procesije pojavljuju nakon odobrenja kršćanstva u 4. st. kada su se u Rimu svakodnevno u drugoj crkvi sakupljali vjernici i potom kretali prema crkvi u kojoj će se održati euharistijska liturgija. U 11. i 12. st. procesije su se održavale u deambulatoriju, ${ }^{28}$ posebnom dijelu crkve. U srednjovjekovlju su posebno bile razvijene procesije s relikvijama kršćanskih mučenica i mučenika. U 16. st. najčešće su bile euharistijske procesije s hostijom u pokaznici. ${ }^{29} \mathrm{Na}$ čelu procesije je križ, potom djeca, pa muškarci, zatim svećenici, niži po časti, iza njih viši, te najčasniji koji nose sakralni predmet. Na kraju povorke su žene. ${ }^{30} \mathrm{U}$ splitskom i kaštelanskom kraju procesije su se nazivale rogacijuni (rogacjuni), ${ }^{31} \mathrm{u}$

\footnotetext{
${ }^{28}$ Deambulatorij - ophodni prolaz koji kruži oko svetišta ili apside. Katkad je povezan s perifernim vijencem kapela. Redovit je u sakralnoj romaničkoj i gotičkoj arhitekturi (usp. Badurina, nav. dj., 199).

${ }^{29}$ Pokaznica (ostenzorij, monstranca) izvorno je označavala svaku posudu u kojoj se izlažu svete moći. Kasnije je taj naziv ograničen na prozirnu spremnicu u kojoj se izlaže posvećena hostija (isto, 464-465).

${ }^{30}$ Usp. isto, 487-488.

${ }^{31}$ Rogacijun - procesija s molitvama za polje.
} 
boko-kotorskom kraju rogazioni, ${ }^{32}$ a u poljičkome procesijuni. ${ }^{33}$ Od 1945. do 1952. godine vlasti su zahtijevale traženje odobrenja za održavanje procesija često ih odbijajući ili sa zakašnjenjem dajući odobrenje. Od 1952. godine sve su procesije izvan crkvenoga prostora bile zabranjene. Zbog zabrana vjernici su u još većem broju sudjelovali u procesijama i išli na misu. Kazivačica, primjerice, u Lišanima Ostrovičkim pripovijeda:

»Za dešpet smo svi išli na misu, što komunisti nisu dali; što su više zabranjivali, mi smo više išli; to nam nitko nije mogao zabraniti..«34

U metkovskom kraju tradicionalno procesija ide iz Borovaca u Nova Sela. Nekoć se u crkvu za blagoslov nosio luk ${ }^{35}$ i sabljak. Blagoslovljeni luk i sabljak križao bi se i davao ovcama i kozama vjerujući da ih neće zmija ugristi. Svećenik bi uz to blagoslovio i polje, brdo i ljude koji su tu bili. Moli se sv. Marka da zaštiti od nevremena, munja i tuče. ${ }^{36}$

Nekoć su se nosile zastave, tri svijeće, te bi se na tri mjesta stalo, a potom blagoslivljalo na sve četiri strane. Na blagoslov su se nosili luk, mrkva, a nakon toga bi se polagalo živini da okusi blagoslovljeno povrće. Post i mise su uobičajeni neizostavni običaji.

Zaštitnik sela Tolise u Bosanskoj posavini je sv. Marko. Uoči toga dana, koji se u puku zove kirbaj, u večernjim satima u selu se igralo kolo. Za to pučko veselje kaže se da »igra kobila«. Tu večer i staro i mlado odlazi u selo, gdje se »divani«, pjeva, veseli te tako mještani dočekuju svoj kirbaj. ${ }^{37} \mathrm{Na}$ Markovdan je blagosov, a običaji su vrlo slični kao i u ostalim okolnim selima za kirbaj. ${ }^{38} \mathrm{Na}$ blagoslov misa obično započne pjesmom:

\footnotetext{
${ }^{32}$ Naziv rogazioni dolazi od talijanske riječi koja znači blagoslov mora, šuma i polja. »Na sv. Vicenac smo odili na rogazione. Kad su rogazioni bili na Muo ćahu blagosivljat mreže i more. Kad bi pasavala procesija sa lancanom od crkvene bandijere doticali su mreže, a križ su stavljali u trikrat u more, a kampane su zvonile. U Tivtu, Mrčevcu, Bogdašićima i Kavču vezivali su arkulić o pas i blagosivljenom vodicom bi posipali intradu i sve oko kuće. Intrada bi bila sva ta polja, odnosno vrtovi koji su zasađeni maslinama, pamidorom, krastavcima. Blagosivljali bi i šumu i to svi seljani koji bi išli sa arkulićem, a arkulić je jedna posuda od terakote u koju bi punili svetu vodu i blagosivljali intradu « - zapisala Iva Brguljan u Kotoru 2006. godine, a kazivala joj Sonja Nikolić, rođ. Brguljan (FF MO, 2006, D).

${ }^{33}$ Usp. Frano IVANIŠEVIĆ, Poljica. Narodni život i običaji, reprint izdanja JAZU iz 1906. i neobjavljena građa, Split, Književni krug Split, 1987, 453.

${ }^{34}$ Anđela Mijić zapisala je 2015. godine u Lišanima Ostrovičkim, a kazala joj je Mara Mijić iz Vukšića, djev. Ledenko, udovica Ante Mijića. Kazivačica pamti pravo bogatstvo hrvatske usmene književnosti i tradicijske kulture (FF ST, 2015, S).

${ }^{35}$ Crveni luk uzgajao se u Mezopotamiji i Egiptu prije 6.000 godina. U mnogim zemljama crveni luk je bio sveta biljka i nije se smio jesti. Poznata je staroslavenska izreka da je crveni luk lijek za sedam bolesti. Crveni luk je najčešća biljka na freskama egipatskih grobnica. U drevnom Egiptu prisega pred lukom predstavljala je najviši oblik prisege.

${ }^{36}$ Matija Manenica zapisala je 2010. godine u Borovcima u Neretvanskoj krajini, a kazala joj je Kata Ereš, djev. Manenica, rođ. 1926. godine u Borovcima (FF ST, 2014, D).

${ }^{37}$ Magdalena Ilišević zapisala je 2013. godine, a kazala joj je Manda Ilišević iz Tolise, djev. Ivkić, rođ. 1936. (FF MO, 2013, Z).

${ }^{38}$ Ružici Krnjić 2012. godine kazala je Janja Martinović iz Ugljare, djev. Grbešić, rođ. 1951. (FF
} 
Faljen Isus, Marijo,

faljen Isus, Djevice,

faljen Isus, Majko naša,

zagovornice.

Došli smo te proslavit

s andelima pozdravit:

Ti od Boga nadarena

Gospo blažena,

primi nas sve putnike,

tužne ćeri i sinke,

primi, Gospo draga, sada

nas nevoljnike,

koji smo ti hrlili,

od srca se trudili

i na ovo sveto mjesto željno

sad smo dospjeli. ${ }^{39}$

Na sam kirbaj, punoljetne djevojke oblačile bi svečanu narodnu nošnju koja se u tome kraju naziva bresuknjača. To je bio znak da je djevojka spremna za udaju. Djevojke koje su dolazile iz bogatijih obitelji, ${ }^{40}$ vezale su dukate oko vrata te bi tako još više privlačile mladiće.$^{41} \mathrm{U}$ Đakovštini je na Markovo prvi blagoslov polja. Ide se u crkvu, a poslije podne se ne rade niti kućni poslovi. Blagoslov njiva, polja, oranica održava se i u Babinoj Gredi. Ujutro se od kuće ponese pšenice i ide u crkvu na svetu misu. Popodne se ponese blagoslovljene vode i ide blagoslivljati njive i polja. ${ }^{42}$

Početkom 20. stoljeća imotska je tradicija bila da je na Sv. Marka blagdan do podne, a od podne se radi. Ujutro je misa nakon koje je bio blagoslov cvijeća. Iz svake kuće bi jedna ženska osoba u torbi ponijela trave koju bi svećenik posebno blagoslovio na svršetku mise. Od te trave svakoj se živini davalo po šaku. Govorilo se: »Ova trava čuva blago od bolesti i uroka.« Obavljala su se četiri blagoslova polja. ${ }^{43}$

U Vinjanima Donjim uvijek je bio blagoslov polja pa je svećenik govorio kao i danas: »Od munje, grada i tuče«, a narod bi odgovarao: »Oslobodi nas Gospodine«. Danas se sv. Marko slavi u Podbablju, gdje mu je i crkva. ${ }^{44}$

\footnotetext{
MO, 2012, S).

${ }^{39}$ Isto.

${ }^{40}$ Starije žene uvijek su za djevojke iz bogatih obitelji govorile: »Ne ljubi se što je pribogato, već se ljubi što je umiljato!«, kazala je spomenuta Manda Ilišević.

${ }^{41}$ Isto.

${ }^{42}$ Matea Ćosić zapisala je 2012. godine, a kazala joj je Sofija Pavlović iz Babine Grede, djev. Lešić, rođ. 1946. (FF MO, 2012, D).

${ }^{43}$ Usp. Silvestar KUTLEŠA, Život i običaji u Imockoj krajini, Imotski, Matica hrvatska ogranak Imotski, 1997, 278.

${ }^{44}$ Kristina Ćapin zapisala je 2011. godine, a kazala joj je Janja Aračić iz Vinjana Gornjih, rođ. 1926. (FF ST, 2012, D).
} 
Obred blagoslova polja u Prološcu bi se održao na prikladnom uzvišenju, mjestu nedaleko od crkve, odakle se vidi veći dio polja. Ali, ako bi bilo nevrijeme, blagoslov bi se obavio u crkvi. U Prološcu bi toga dana procesija izašla na vrh Kokića glavice, odakle bi svećenik blagoslovio cijelo polje. Tog bi dana sve žene i cure skinule sa sebe zimsku crnu odjeću, a oblačile bi prvi put u godini bijele košulje. Bijelo se nosilo do struka i to čitavo vrijeme sve do blagdana sv. Luke, 18. listopada. Prije Sv. Marka u Prološkom Blatu nitko ne bi sijao kukuruz. Toga dana krenuli bi orači jedan za drugim niz polje tjerajući svatko svoju zapregu volova ili konja. Žurili bi da bace prvo zrno i zaoru. ${ }^{45}$

U Podbablju svećenik bi polja blagoslivljao na četiri mjesta i to na četiri mosta: najprije na Gozdenjaku, Malom mostiću, Bublinu i Kamenmostu. Svećenik govori: »Po znamenju svetoga križa, od neprijatelja našega, puk oslobodi nas, Bože.« Narod odgovara: »Oslobodi nas, Bože.« Potom dolaze tri svijeće i svećenik govori: »Od munje, groma, grada i biča trešnje oslobodi nas, Gospodine.« Kasnije se to biča trešnje ${ }^{46}$ promijenilo u - svakoga zla vrimena. $\mathrm{Uz}$ uskršnju svijeću svećenik moli: »Da se dostojiš plodove zemlje dati i uzdržati.« Puk odgovara: »Tebe molimo, usliši nas!« Potom slijedi blagoslov blagoslovljenom vodom uz svećenikove riječi: »Da kišu zdravu, obilnu i plodonosnu ovoj zemlji u vremena potrebita udijeliš. « Na to puk odgovara: »Tebe molimo, usliši nas!« Zatim svećenik koristeći kadionik govori: »Da vjetrove škodne i nevaljele ukrotiti i poniziti udostojiš«, a puk opet odgovara: »Tebe molimo, usliši nas!« Zatim se procesija upućuje prema drugome, trećem i zadnjem mostu i na svakom se isto moli, dok se u putu do sljedećega mosta mole Litanije svih svetih. Po svršetku obreda ide se u crkvu i služi se sveta misa. ${ }^{47}$

Radi blagoslova polja sav narod u župi runovićkoj svetkuje do podne, a onda od podne radi. Imaju četiri blagoslova polja koje župnik čini u pratnji naroda. ${ }^{48}$

Kad je bio blagoslov polja varošani u Splitu u procesiji su išli na Marjan. S vrha Marjana, gdje je sada Gospa od Betlehema, blagoslivljalo se polje. (Varošani su imali polja u Špinutu i Mejama.) Lučani su išli prema Visokoj i odatle se blagoslivljalo polje. Išli su poljem, otprilike gdje je danas Vukovarska ulica. Kad bi došli do Visoke spustili bi se dolje gdje je Sv. Lovre. U Sv. Lovre bi bile molitve, a potom bi se vraćali prema Splitu, zaustavljajući se na pojedinim mjestima. ${ }^{49}$

\footnotetext{
${ }^{45}$ Ines Ivelja zapisala je 2008. godine, a kazivale su joj Iva Juričić, zvana Rabotuša, djev. Klarić, rođ. 1912. i Jela Dračar, zvana Jeluša, djev. Bajić, rođ. 1935. (FF ST, 2008, S).

${ }^{46}$ Biča trešnje se govorilo jer je bilo čestih potresa.

${ }^{47}$ Anamarija Ivkošić zapisala je 20. kolovoza 2010. u Podbablju, a kazala joj je Dinka Ćapin, zvana Kosa, djev. Kujundžić, rođ. 1937. (FF ST, 2012, D).

${ }^{48}$ Ivan Perić snimio je 8. lipnja 2010. na Kamenmostu, a kazao mu je Marijan Perić, zvan Kasalušin, rođ. 1925. (FF ST, 2010, S).

${ }^{49}$ Marina Jurišić zapisala je u Splitu 2007. godine, a kazao joj je Perislav Petrić, rođ. 1920. u Splitu; do mirovine je radio kao profesor fizike i matematike (FF ST, 2011, D).
} 
U Mravincima kod Splita procesija je išla preko Krušćića, pa ispod Tentinih kuća, ispod Jelčke i putem kroz Lozinice se vraćala u crkvu. Na četiri postaje su se čitala četiri evanđelja. ${ }^{50}$

U kaštelanskom kraju procesija je od župne crkve išla prema polju. Usput bi se zaustavila na četiri mjesta, ispjevala bi se četiri evanđelja pa bi svećenik dao blagoslov. Uzeo bi u ruke križ te okrećući se na četiri strane svijeta pjevao: »Evo križ Gospodinov, bižite strane suprotivšćene, pobidija je Krist Gospodin, lav iz kolina Judina, koren Davidov, aleluja!« Onda bi, držeći uskrsnu svijeću, molio da Bog uzdrži urod, da ga sačuva od svake bolesti i da zdravo dođe do zrelosti. S kadionicom u ruci molio bi: »Da sve vitre i oblake umiriti i ukloniti dostojiš se! « ${ }^{51}$

Lokvičani su na Markovo išli na oltar zvani Gradina. Najprije bi išli u crkvu, a na svakome ćošku bi se blagosov govorio; i sva četri evenđelja bi se čitala. Tjedan dana nakon Markova bi u procesiji išli do jedne ledine s koje se polje vidjelo. Tada bi se polje blagoslivljalo. Svećenik bi se okrenuo prema polju i s vjernicima molio: »Blagoslovi, Gospodine, brda, polja i doline, sirotice, udovice i ostale nevoljnice. ${ }^{52}$

Za vrijeme blagoslova polja škabrnjsko polje je bilo zavjetno. Prije obreda je bila »borba« dječaka tko će »nosti barjak«, kao što je bilo i za Veliku Gospu, koja će od djevojaka »nosti Gospu«. Biralo se koji će mladići nositi barjak. Svaki je mladić koji je nosio križ dobivao vina. Prije bi svatko davao vina za svećenikovu konobu. U procesiji je prvi išao križ, onda barjaci, a za barjacima ide narod u procesiji. Nekoć bi se išlo iz crkve pravo u Ivkoviće; pa na bunar Ikovac dolje; od bunara Ikovca na Škarin bunar; sa Škarinog bunara na Graviće. Od Gravića se išlo na bunar Zagrljak na Prkos, od bunara Zagrljka se išlo na Pletenice, od Pletenica gore na Brižine i od Brižina pravo na Sv. Mariju. Od Sv. Marije kroz Ambar vraćalo se u crkvu. »Tako j' išla procesija za blagoslov na Markovo.«53

Prije 160 godina blagdan sv. Marka u Slavoniji krakterizirao je blagoslov polja i usjeva. Svećenik s mnoštvom svijeta pod crkvenim zastavama, s križem, svetom vodom i kadionicom tamjana u procesiji bi došao u polje na zasijane njive, gdje bi se po crkvenim propisima obavio obred blagoslova. Od svakoga evanđeliste, pjevalo se po jedno evanđelje te bi se škropio usjev i kadio tamjanom. Djevojke bi od žitnih vlati isplele vijence i nakitile križ i zastave. ${ }^{54}$

Ujutro na Markovo, u Gundincima, iz crkve je išla procesija sve do kraja sela gdje se na prvoj njivi zasijanoj pšenicom svetilo žito. To žito je bilo već u trećem

\footnotetext{
${ }^{50}$ Veronika Bućan zapisala je u Mravincima 2009. godine (FF ST, 2009, S).

${ }^{51}$ Andrea Petra Radman zapisala je 2012. godine, a kazala joj je Tonka Čmrlec, djev. Britvić, rođ. 1933. (FF ST, 2012, S).

${ }^{52}$ Tanji Pezo kazala je u prosincu 2008. godine u svojoj kući u Splitu Slava Pezo, djev. Bekavac, rođ. 1947. u Lokvičićima (FF ST, 2009, D).

${ }^{53}$ Antonija Pavičić zapisala je 2010. godine u Škabrnji, a kazao joj je Zoran Ražov, rođ. 1965. (FF ST, 2010, S).

${ }^{54}$ Stojanović, nav. dj., 51.
} 
koljenu i od njega su djevojke pravile mali vjenčić koji se metao na križ. Svaki sudionik procesije iščupao bi jednu vlat žita koju je nosio kući..$^{55}$

Diljem Slavonije svako selo u svom ataru u polju ima križ. Jedne nedjelje u proljeće, kad je žito još mlado, održavala se posveta polja. Dan prije cure i momci odu u polje i nakose snopove mladog žita i ostave ga uz križ. Cure od njega ispletu vijence koji se stavljaju na raspelo i nose se u procesiji. U nedjelju ujutro ili na Markovo - jer je on zaštitnik polja - svi župljani idu u crkvu gdje se nakon mise u procesiji kreće u polje, do križa. Na čelu procesije momci nose jedno veće i jedno manje raspelo, a za njima ministranti, župnik i ostali vjernici. Kad dođu do križa tamo već bude postavljen oltar i na njemu snopovi žita. Nakon molitve župnik uzme raspelo okićeno vijencem spletenim od žita, podigne ga i okrene se na jednu stranu svijeta te izgovara riječi: »Sačuvaj nas, Bože, kuge, glada i rata.« Mnoštvo odgovara: »Oslobodi nas, Gospodine.« Zatim se župnik okrene na drugu stranu svijeta i izgovara riječi: »Sačuvaj nas, Bože, od vatre, leda i groma.« Svijet odgovara: »Oslobodi nas, Gospodine.« I tako još dva puta na svaku stranu svijeta. Nakon toga župnik blagoslovi žito na oltaru, te svatko uzme po stručak posvećenog žita i ponese doma da ga zatakne za svetu sliku na zidu u kući. Time su ljudi iskazivali vjeru da će im Bog sačuvati polja i usjeve, a posebno žito jer u Slavoniji dobra i rodna žetva, te puni hambari jamče svaki dan kruha na stolu. ${ }^{56}$

Blagoslov žita počinje na zajedničkoj svetoj misi. Poslije mise vjernici su se iz crkve u procesiji kretali prema polju. Na čelu procesije nosi se križ, momci sa strane, okruženi djevojkama, nose crkvene barjake, za njima ide svećenik predvodeći Litanije svih svetih, koje se najčešće pjevaju. U molitvi vjernici zazivaju spominjane svece za zagovor kod Boga. Mole i za obilan rod na svim poljima. Svećenik obavlja obred blagoslova tako da najprije pročita četiri evanđelja i poslije svakog se okreće na drugu stranu svijeta, moleći se za sve njive u okolici. Poslije prigodne molitve svećenik blagoslovi žito, s tim i sva žitna i druga polja. Sv. Marko je zaštitnik ne samo žitnih polja, već svih polja jer u okolici ima i vinograda i voćnjaka. ${ }^{57}$

Od Markovdana po kreševskim grobljima počinju blagoslovi i mise, a i derneci. Toga dana gore težačke svijeće. ${ }^{58}$ Običaj je da se tada sabere sva rodbina na grobovima svojih najmilijih, zapale svijeće i mole molitve. Rodbina koja živi na selima zove rod i prijatelje na užinu. Zanimljivo je da sve do naših dana na

\footnotetext{
${ }^{55}$ Barbara Smajić zapisala je 2010. godine u Gundincima, jednom od najistočnijih mjesta Brodsko-posavske županije, a kazala joj je njezina baka Marija Horvatović, djev. Užarević, rođ. 21. siječnja 1931.; cijeli svoj život provela je u Gundincima (FF ST, 2010, S).

${ }^{56}$ Ema Reitober zapisala je 2007. godine u Bočkincima kod Donjeg Miholjca, a kazala joj je Slavica Barić, djev. Zdelar, rođ. 1960. (FF ST, 2007, S).

${ }^{57}$ Ina Kedžo zapisala je 2010. godine, a kazala joj je Božica Grdenić iz Vinkovaca, djev. Bilonić, rođ. 1975. u Vođincima kraj Vinkovaca (FF ST, 2012, D).

${ }^{58}$ Augustin KRISTIĆ, Crkveno-narodni običaji Kreševa, poseban otisak iz »Dobrog pastira«, Sarajevo, 7 (1956) 17.
} 
užinu pozivaju samo mještani iz okolnih sela, dok mještani Kreševa ne pozivaju na užinu. ${ }^{59} \mathrm{~Sv}$. Marko u kreševskom kraju smatran je težačkim svecem ili kao svetac »domišnjak«. Nakon jutarnje mise domaćini oru siromasima. Tada je osobito naglašena molitva: »Da se dostojiš, Bože, plodove zemlji dati, uzdržati i blagosloviti! « ${ }^{60}$

Na ovaj dan, u posuškom kraju, počinje blagoslov polja i održavanje misa po grobljima. Mise se održavaju svake nedjelje na drugom groblju i moli se za obilan usjev. Ni jedno groblje u župi ne smije biti zapostavljeno, pa održavanje misa po grobljima traje sve dok se u zadnjem zaseoku kojeima groblje ne održi misa. Poslije mise običaj je da se rodbina i prijatelji svraćaju na ručak. Tada se pripremi obilan ručak, a od pića pije se obično vino i rakija. Nazdravlja se za dobar usjev i da Bog dadne dovoljno kiše kako bi sve posađeno moglo roditi. ${ }^{61}$

Bunjevački Hrvati su na Markovo slavili proklijali usjev i ozelenjelo polje te blagoslivljali žito i vinograde. 62

\subsection{Negdašnji običaj blagoslova polja u Kostanju}

Blagdan sv. Marka bio je dan kada je u Kostanju narod zahvaljivao za dar svih plodova koje nam Gospodin udjeljuje preko polja, njiva i mora, za sve ono čime Bog blagoslivlja naš rad i trud kojim ostvarujemo dostojan život.

U pamćenju je ostao blagoslov polja: U stara doba na četiri brdašca u selu bio je križ i na sva četiri mjesta se hodočastilo, a svećenik je nosio križ. Čak je bio, neki kažu, jedan stari svećenik koji nije mogao hodati, nego su ga nosili, a narod je išao za njim. To je bila velika procesija, dugo je trajala. Dugo je trebalo hodati dok se obiđu sva četiri mjesta. Hodalo se nekoliko sati, a sve radi zahvaljivanja Bogu za sve djelatnosti kojima se ljudi bave, da svaki rad bude blagoslovljen i pošten. Danas se procesija obavlja samo oko crkve. ${ }^{63}$

Nekoć je na blagdan sv. Marka svake godine bio dug obred blagoslivljanja polja. Procesija bi išla s jednog na drugi kraj sela, a postaje su bile na više mjesta, obično na brežuljcima. Na svakom brežuljku bio je istaknut križ. Na svakoj postaji čitala su se evanđelja i zazivali blagoslovi, kao npr: »Od munje, groma i grada sačuvaj nas, Gospodine«, »Daj nam kišu ugodnu, godinu plodnu i rod-

\footnotetext{
${ }^{59}$ Sanela Vujica zapisala je 2010. godine, a kazao joj je Anto Kraljević, rođ. na Glavicama pored Kreševa 1931. (FF MO, 2010, D).

${ }^{60}$ Kristić, nav. dj., 17.

${ }^{61}$ Antonija Širić zapisala je 2009. godine, a pripovjedio joj je Frano Širić, rođ. 1933. u mjestu Cerovi Doci kod Posušja (FF MO, 2010, D).

${ }^{62}$ Bunjevački narodni običaji kalendarske godine www.sulinet.hu/oroksegtar/data/magyarorszagi_nemzetisegek/horvatok/csavoly/iz_osamstoljetne_kronike_cavolja/pages/013_bunjevacki_narodni.htm (19.02.2016).

${ }^{63}$ Ana Bašić zapisala je 2011. godine u Kostanju u Poljicima, a kazao joj je Stipe Bašić, zvani Stipan, rođ. 1955. U Kostanju živi cijeli život i jako dobro poznaje život u selu, posebice crkvene običaje koji ga najviše i zanimaju te nerijetko provodi svoje slobodno vrijeme čitajući stare crkvene spise ili pak povijesne knjige (FF ST, 2013, Z).
} 
nu« i drugi slični zazivi za blagosov polja. ${ }^{64}$ Poslije blagoslova blagoslivljali bi se drveni križevi koje su ljudi sa sobom donijeli i ti bi se križevi nosili u polje i tamo bi ostali cijelu godinu.$^{65}$ Negdašnji običaji javnoga blagoslova polja i rada ljudskih ruku u Kostanju je iščeznuo.

\subsection{Križ u Jardolu kod Viteza}

Ni najstariji Jardoljani koji pamte pripovijedanja svojih predaka ne znaju kada je tu postavljen križ. Samo znaju da je posvećen ovdašnjem težaku i proljetnom svecu, sv. Marku.

Lokalitet na kojem je postavljeno molitvilište, nazvan je »Križ«. To duhovno naslijeđe ostavili su preci. Nekada bi se, načet zubom vremena, križ srušio i baš tada bi godina krenula po zlu. Zavladale bi velike suše ili bi naišla tuča i otukla zasijano žito. Te bi godine vladala glad, a kad je križ obnovljen tada bi vjernici na blagdan sv. Marka tu molili vjerujući da će Božjom voljom oluja zaobići Jardolsko polje. Stariji Jardoljani pričaju da je križ najčešće obnavljao Marko Topalović, rođen 1900. Ispod križa, tridesetak metara s lijeve strane, pravilno je raspoređena valovita podloga. Prema predajama tu su gropčići ukopane djece umrle u mističnim okolnostima. Rodilje koje bi izgubile mlijeko dolazile bi s još nekoliko žena iz sela i molile litanije ili rožarije za dobivanje mlijeka. Pripovijeda se da je to mnogim rodiljama pomoglo da im se u grudi vrati mlijeko. ${ }^{66}$

\subsection{Pomaganje sirotinji}

Kult sv. Marka u Hrvata svjedoči i pomaganje sirotinji na Markovdan. Ramska i uskopoljska tradicija jest da se na Markovdan sirotinji pooru njive, često donoseći i svoje sjeme, da im ne ostanu nezasijane. ${ }^{67}$ (Isto se činilo na Veliki četvrtak.) Nekoć su, primjerice, u Uskoplju i Rami na Markovdan domaćini svećeniku darivali najbolje janje ili jare. ${ }^{68}$ Postoji narodna zapovijed i običaj da na taj dan oni koji imaju plug i zapregu ne oru svoju zemlju nego su dužni nekome siromahu orati $d \check{a} a b e$ (bez naknade). ${ }^{69}$

\footnotetext{
${ }^{64}$ Marijana Radovčić zapisla je 2010. godine na području Kostanja i Seoca, a kazali su joj Zorka Gojsalić, djev. Rubić, rođ. 1937. u Kostanju, Jozo Radovčić, rođ. 1957. u Kostanju, Kruna Radovčić, rođ. 1943. u Seocima i Jelica Zubanović, djev. Jerončić, rođ. 1940. u Seocima (FF ST, 2011, D).

${ }^{65}$ Isto.

${ }^{66}$ Mateja Rajković zapisala je 2009. godine, a kazivao joj je Ljubomir Pavlović, rođ. 1944. u Vitezu (FF MO, 2009, S).

${ }^{67}$ Zapisao sam 1997. godine (Vl. rkp. zb.).

${ }^{68}$ Isto.

${ }^{69}$ Kazao je spomenuti Ljubomir Pavlović.
} 


\section{Pučke divinacije i izreke}

U Imotskoj krajini vjerovalo se: ako na Markovo padne malo kiše, makar da samo volu stopi rog, da će godina biti rodna. ${ }^{70}$ Isto se vjerovalo, primjerice: u Lokvičićima, ${ }^{71}$ Kamenmostu, ${ }^{72}$ Usori ${ }^{73}$ Rami $^{74}$ i dr. Također je stara ramska tradicija da je od toga dana sunce zdravo.

U zapadnoj Hercegovini govori se: »Nema jutra bez Jurjeva jutra. Nema danka bez Sv. Marka.« Jurjevo jutro smatra se najčistijim i najzdravijim, a pravi i lijepi sunčani danak je na sv. Marka. »Toga dana sve životinje počinju hodati i zmije listi.. ${ }^{75}$ U Dalmatinskoj zagori poznata je izreka: »Drži u njidrin ruke i ne vadi vanka do Sv. Marka. ${ }^{76}$ U Grohotama na Šolti obred iznošenja bijeloga barjaka prati usklik: »Na Sv. Marka bila bandira vanka! ${ }^{77} \mathrm{Uz}$ Jurjevišće i Markovišće, u Vinišću, se govori: Jurjevišća, Markovišća / među njima dan godišća. Time se želi kazati da je između Jurjeva i Markova dana stajao samo dan razlike, a to razdoblje se smatralo najpogodnijim za sadnju graha i povrća. ${ }^{78}$ Stari je poljički običaj bio jutarnji procesijun, a popodne se sije rasad kupusa. Vjerovalo se da ako kiša padne na taj dan, da oskoruše neće imati ploda. ${ }^{79}$

U busovačkom kraju, od Sv. Marka sve se može »sijati po vrtlu, od povrtalja, posebno grah jer nema mraza da ga ubije«. Tada počinje u našim krajevima blagoslov groblja i polja. ${ }^{80}$ Neki su u Kijevu na posvetu nosili i komad procvjetalog crnog trna, te se to stavljalo djetetu na sva četiri ćoška krevetića. Vjerovalo se da to štiti od vištica. ${ }^{81}$

Vjeruje se da je najbolja zaštita protiv more kada se četiri crna trna, posvećena na Markovdan u crkvi, stave u svaki kut kreveta po jedan. Za obranu od te napasti još je dobro uzeti končić iz crkvene odjeće (svećenička košulja, štola

${ }^{70}$ Kutleša, nav. dj., 278.

${ }^{71}$ Kazala je spomenuta Slava Pezo.

${ }^{72}$ Kazao je spomenuti Marijan Perić, Kasalušin.

${ }^{73}$ Zapisao sam 2006. godine (Vl. rkp. zb.).

${ }^{74}$ Isto.

${ }^{75}$ Listi = gmizati; usp. Jerko SUTON, Vjerski život i običaji Zapadne Hercegovine, Mostar, 1968, 113; umnožen rukopis, a primjerak se nalazi u Franjevačkoj knjižnici u Mostaru, inv. br. 3912, sign. 39.

${ }^{76}$ Ana Čavka zapisala je 2015. godine, a kazala joj je Jaka Bašić, djev. Delić, rođ. 1938. u Lećevici (FF ST 2015, S).

${ }^{77}$ Bandira = barjak; Victoria Vestić zapisala je 5. svibnja 2013. godine u Grohotama na Šolti, a govorila joj je Tereža Sule, rođ. 1935. (FF ST, 2013, S).

${ }^{78}$ Ana Bašić zapisala je u Vinišću 2014. godine, a kazala joj je Cvita Marušić, rođ. 1918. (FF ST, 2015, S).

${ }^{79}$ Usp. Ivanišević, nav. dj., 452.

${ }^{80}$ Slađana Miličević zapisala je 2010. godine u selu Ravan kod Busovače, a kazali su joj njezini djed i baka iz sela Ravan pokraj Busovače, Vlatko Petrović, rođ. 30. svibnja 1939., i Milica Petrović, djev. Laštro, rođ. 17. rujna 1944. (FF MO, 2013, Z).

${ }^{81}$ Jelena Vrcelj zapisala je 2010. godine, a kazala joj je Dragica Čavka iz Sinja, rođ. 3. prosinca 1956. u Kijevu (FF ST, 2010, S). 
i sl.). ${ }^{82}$ Drevno je vjerovanje u Primorskom Docu da onaj koji na Markovo nađe zelembaća treba zabiti trn u njega i koliko trnja zabije toliko će mu se grijeha oprostiti. Međutim, nikada nitko nije vidio zelembaća na Sv. Marka, a njegova koža je toliko čvrsta i debela da kroz nju trn ne može proći. ${ }^{83}$

U Imotskom misa je ujutro, a nakon mise slijedi blagoslov polja i cvijeća. Žene bi na misu ponijele i trave koju bi svećenik blagoslovio. Blagoslovljena trava se čuvala i pridavana su joj apotropejska svojstva. Vjerovalo se: ako na Sv. Marka padne kiša, da će biti dobra godina. ${ }^{84}$ Prološke žene i djevojke bi našle i ubrale što veće trave prije odlaska u crkvu toga jutra. Travu bi zavezale i nosile sa sobom na blagoslov. Blagoslovljena trava dala bi se marvi za zdravlje. ${ }^{85} \mathrm{Za} \mathrm{Sv}$. Marka u svim imotskim župama nosila se djetelina na blagoslov jer se vjerovalo da će sačuvati živinu od bolesti, zmije i svakoga nemila.$^{86}$ Nekoć je na taj dan u župi runovićkoj bio blagosov cvijeća, pa je iz svake kuće jedno žensko trebalo nositi torbicu trave koju bi misnik posebno blagoslovio na svršetku svete mise. Od te trave davalo se svakoj svojoj živini po šaku vjerujući da to čuva blago od bolesti i uroka. ${ }^{87} \mathrm{U}$ selu Ceri, pored blagoslova polja, blagoslivljala se i gospina trava ili djetelina. Za vrijeme mise svećenik bi s okupljenim vjernicima izašao na polje i tamo bi blagoslovio maslinove grančice koje bi vlasnici zaboli u svoj dio polja. Nakon toga su se blagoslivljale gospina trava ili djetelina. Izbor između tih dviju vrsta trave ovisio je o tome koja je dostupnija i koje ima više. Ta bi se trava nakon blagoslova nosila kući, gdje bi je gazda izrezao i pomiješao $s$ hranom za ovce. Tada bi se sve to dalo ovcama da jedu. Vjerovanje je bilo da će ta trava donijeti zdravlje životinjama u toj godini. ${ }^{88}$

Na Markovdan se u Kijevu obavlja blagoslov polja, a u crkvu se donosi trava rosopad $^{89}$ koja se poslije blagoslova nosi kući i daje blagu. Budući da je ta trava gorkog okusa, razmrvi se i pomiješa s djetelinom i daje stoci. Osim rosopada posvećivao se i korijen tikvine..$^{90}$

\footnotetext{
${ }^{82}$ Usp. isto.

${ }^{83}$ Ivana Goreta zapisala je 2010. godine, a kazala joj je Olga Brkić, djev. Kalpić, rođ. 1940., koja kroji i prepravlja narodne nošnje. Primorski Dolac je mjesto u Dalmatinskoj zagori, na zapadu Splitsko-dalmatinske županije. Nalazi se između dvije manje planine, Trovro i Praća. Sastoji se od više zaselaka koji se uglavnom nazivaju prema prezimenima ljudi koji su se tu naselili: Gornji Dolac, Kalpići, Franići, Barići, Šustići, Bakovići, Podari, Žunići, Stojaci, Balovi, Akažići, Dračari i Donji Dolac. Kao što su i većina sela izgubila svoje stanovnike jer su se odselili u gradove, tako se dogodilo i s Primorskim Docem u kojem sad živi oko 1000 stalnih stanovnika: »uglavnom starijih ljudi koji su često tamo zaboravljeni i rijetko posjećivani od strane svojih najbližih« (FF ST, 2010, S).

${ }^{84}$ Martina Knezović 2011. godine zapisala, a kazivale joj Marija Kilić, djev. Knezović, rođ. 1951. i

Tonka Knezović, djev. Knezović, rođ. 1959., obje rođene i odrasle u Imotskom (FF ST, 2011, S).

${ }^{85}$ Kazale su spomenute Iva Juričić, Rabotuša i Jela Dračar, Jeluša.

${ }^{86}$ Kazala je spomenuta Dinka Ćapin, Kosa.

${ }^{87}$ Kazao je spomenuti Marijan Perić, Kasalušin.

${ }^{88}$ Nikoli Sunari 2008. godine kazala je Matija Sunara (FF ST, 2008, S).

${ }^{89}$ Rosopad (rosopas) - ljekovita biljka koju narod naziva Božji dar ili Marijina biljka.

${ }^{90}$ Kazala je spomenuta Dragica Čavka.
} 
Katolici i pravoslavci u Popovom polju vjeruju, ako je netko spavao na Jurjevdan da treba odspavati i na Markovdan, inače će cijele godine drijemati. ${ }^{91}$ Pravoslavci vjeruju, ako je netko spavao na Jurjevdan da na Markovdan treba spavati na istome mjestu, inače će ga cijele godine boljeti glava. ${ }^{92}$ Tamošnji katolici, do četrdesetih godina 20. stoljeća, na Markovdan nisu radili ništa i više su ga slavili nego Jurjevdan. ${ }^{93}$ Koncem 2015. i početkom 2016. godine istraživao sam tradiciju o sv. Marku u južnoj Hercegovini. Od kazivača s kojima sam razgovarao nitko se ne sjeća nekadašnjih običaja na Markovdan. Jedino u Aladinićima Boškovići sv. Marka Evanđelistu slave kao svoga zaštitnika.

Bunjevački Hrvati vjerovali su, ako na Markovo ne pjeva slavuj proljeće će biti promjenjivo. Dobrim znakom smatralo se ako se u usjevu može sakriti vrana. ${ }^{94}$

$\mathrm{Na}$ Jurjevo, a u nekim omiškim selima na Markovo, seoska ronda ${ }^{95}$ je nekoć stavljala granice. Pošli bi na »sva četiri vitra« od njihova polja i zadili bi na granicu po jednu ' $v o j k u$ ili bi od stijena načinili malu gomilu, kako bi se znalo dokle je njihovo. To se nazivalo zagajivati. Ukoliko bi živinče iz susjednoga sela prošlo tu granicu imali su pravo odmah ga istjerati. ${ }^{96}$

\section{Krjesovi}

Dol na Hvaru sastoji se od pet dvorova: Stončića dvora, Duževa dvora, Ploča, Radoševića dvora i Sansovića dvora. Muška i ženska djeca iz Duževa dvora mjesec dana prije Sv. Marka počeli bi brati grane kite, smardeja, martine, bora i drugoga. To bi nosili na najveću uzvisinu u Dužev dvor - iznad Feretovih na brdo. Žurili bi skupiti što više granja jer će time oganj dulje trajati. Na žežin ${ }^{97}$ sv. Marka, kad bi se smrklo, svatko bi upalio krijes koji se zove Morkovu. Okupilo bi se mnoštvo i mladih i starih. Znalo bi ih biti 50-60. Krijes bi obično trajao do ponoći, kada bi djeca išla na spavanje, a stariji bi još malo ostali čuvati da se ne bi što okolo zapalilo. ${ }^{98}$ Vatra je magijski izvor moći. Vatra u kršćanskoj sim-

\footnotetext{
${ }^{91}$ Ljubo MIĆEVIĆ, Život i običaji Popovaca, Beograd, Srpski etnografski zbornik, knj. LXV., $1952,161$.

${ }^{92}$ Zapisao sam u Trebinju 2009. godine (Vl. rkp. zb.).

${ }^{93}$ Mićević, nav. dj., 161.

${ }^{94}$ Bunjevački narodni običaji kalendarske godine www.sulinet.hu/oroksegtar/data/magyarorszagi_nemzetisegek/horvatok/csavoly/iz_osamstoljetne_kronike_cavolja/pages/013_bunjevacki_narodni.htm (19.02.2016).

${ }^{95}$ Ronda tal. straža, patrola; rondar - stražar, žandar, redar; zajedno s poljarima bili su čuvari polja; čuvari sela koji su birani na seoskim zborovima.

${ }^{96}$ Marin Juraga zapisao je u Omišu 10. travnja 2008. godine, a kazao je Zoran Juraga, rođ. 20. svibnja 1956. u Splitu; potječe s otoka Murtera kraj Šibenika, a cijeli je život živio u Omišu (FF ST, 2008, S).

${ }^{97} \mathrm{Na}$ žežin = uoči.

${ }^{98}$ Ivana Dužević zapisala je 2012., a kazao joj je njezin otac Ivo Dužević, rođ. 1948. u Splitu (FF ST, 2012, S).
} 
bolici predstavlja mučeništvo i vjerski žar, kao i pobjedu svjetla nad tamom. ${ }^{99}$ Narod vatri pripisuje i karakteristike demona, te se vjeruje da onaj koji preskoči vatru pobjeđuje demone. Bolesti su u narodnoj percepciji demonska bića.

\title{
7. Usmene lirske pjesme i molitve
}

Kult sv. Marka ogleda se i u hrvatskim usmenim lirskim pjesmama:

\author{
Voźila śe borka \\ Voźila śe borka \\ na śvetoga Morka, \\ puna uja i bumboka $a^{100}$ \\ $i$ malene dićice \\ ki pitaju śiśice! \\ U more śe śkipje, \\ Guśpa Śinka źibje! \\ U more śe propado. \\ Guśpa Śinka dopado! \\ Śveti Petar oruźnik \\ ki je Boźji pomoćnik. \\ Bog mu je kjuće dol \\ da otvori vićni roj! 101
}

Barka u navedenoj pjesmi puna je ulja, pamuka i djece. Ulje u kršćanstvu simbolizira znak milosti Božje. U navedenoj pjesmi su motiv i malena dječica. Motiv Krista kako sjedi ili, rjeđe, stoji te polaže ruku djeci na glavu govoreći »Pustite k meni malene« spominje se u sinoptičkim evanđeljima (Mt 19, 13-15; Mk 10,13-15; Lk 18, 15-18). Varijacija te pjesme poznata je u Splitu:
Gingola $^{102}$ se barka
na Svetoga Marka,
puna barka pšenice,
svile i bumbaka.
Svilu ćemo prodati,
bumbak ćemo satkati!
Ko to gori škriplje,

\footnotetext{
${ }^{99}$ Neki narodi vjeruju da će preskakanjem vatre pobijediti neprijatelja. Tako su se, primjerice, u jesen 2005. godine diljem Irana palile vatre te se preskakalo preko njih vjerujući da će tako poraziti SAD koji im je zaprijetio ratom.

${ }_{100}$ Bumbok - pamuk.

${ }^{101}$ Diana Njegovan zapisala je 2010. godine u Komiži na Visu, a kazale su joj Jasna Franičević, djev. Borčić, rođ. 1959. i njezina majka Rosanda Borčić, djev. Karuza, rođ. 1935. (FF ST, 2010, S).

${ }^{102}$ Gingati - ljuljati.
} 


\section{Majka sina ziblje, na moru je galija, pomoga' nas Bog i sveta Marija! ${ }^{103}$}

U obje pjesme u prvom stihu spominje se barka. Na blagdan sv. Marka barka se ljuljala. Lađa (barka) simbolizira Kristovu crkvu. Jarbol na lađi simbolizira križ. Kao i u prethodnoj pjesmi barka je puna pšenice. Pšenica simbolizira blagostanje i zemaljsko izobilje, a u euharistiji označava euharistijski kruh. Zrnje žita je euharistijski simbol Kristove ljudske naravi. »Zaista, zaista, kažem vam, ako pšenično zrno ne padne u zemlju i ne umre, ostaje samo. Ako li umre rodi velik rod« (Mt 16, 24-25; Mk 8, 34-35; Lk 9, 23-24).

Navedene pjesme svojom ritmikom pripadaju uspavankama. Korijeni uspavanki sežu u prvobitne zajednice. Poznaju ih sve civilizacije. Malom djetetu nad kolijevkom uspavanke pjevaju majke, rjeđe očevi, te bake i starija sestra ili brat. Uspavanke izražavaju majčinu snažnu ljubav prema djetetu. U nekim suvremenim zapisima uspavanki opažaju se mitski elementi: srmali beša, na moru kovata, kovale je do tri kujundžije - prvi kuje, drugi pozlaćuje, treći meće zlatne jabuke itd. Najčešći su kršćanski motivi: anđeli (ti na san dolazili). Među rijetkim svecima u uspavankama je sv. Marko, kao u prethodne dvije.

Diljem Hrvatske i Bosne i Hercegovine poznate su mnoge varijacije molitava u kojima se vjernici na uskrsno jutro obraćaju obraćaju Gospi tražeći dar za dobar glas jer je Isus uskrsnuo:
Faljen Isus, Gospe moja!
Daj mi dobar dar,
a ja ću tebi dobra glasa
od Isusa Sina tvoga.
Jutros ti je uskrsnuo,
na nebesa uzašao.
Daj mi, Gospe, daj,
na umrli dan,
Ko što je tebi na
jutarnji dan.
Neću ti ništa od dara, nego Sina neumrla daj,
najveći mi je to dar. ${ }^{104}$

Na Pagu se nekoć na usmenom predajom prenosila molitva koja se molila na uskrsno jutro:

\footnotetext{
${ }^{103}$ Iris Olujić zapisala je 2009. godine, a kazala joj je Slavka Ljubica, rođ. 1950. u Splitu (FF ST, 2009, D).

${ }^{104}$ Ana Stojanović zapisala je 2009. u Trišćanima, a stihove kazivala Mare Pavlović, djev. Radić, rođ. 1926. u Trišćanima (FF MO, 2009, D).
} 


\begin{abstract}
Kad uskrsnu Isus sveti, koji za nas bi propeti. Tu se čuda dogodiše, kako sveti Marko piše, i zlamenja mnoga biše.

Ne može se više reći, jer uskrsnu slavan dosti i bez smrti $i$ bez žalosti. ${ }^{105}$
\end{abstract}

U navedenoj molitvi iskazuje se sreća zbog Kristova uskrsnuća i mnogim čudima o kojima piše sv. Marko.

\title{
Zaključak
}

Sv. Marko Evanđelist rođen je oko 10. godine u Cireni, a mučeničku smrt podnio je 25. travnja 68. godine u Aleksandriji. Sv. Petar bio mu je kum i nazivao ga je svojim (duhovnim) sinom. U Novom zavjetu spominje se osam puta, a deveti put se spominje Marija, majka Ivana zvanog Marko. U domu njegove majke Marije okupljala se prva kršćanska zajednica u Jeruzalemu. Po nekim izvorima Isus je posljednju večeru blagovao u kući Markove majke Marije. Marko je bio tajnik sv. Petra i njegov tumač grčkoga jezika. Na misijskim putovanjima bio je sa sv. Pavlom te sa svojim ujakom sv. Barnabom.

O čudima koja su se dogodila po zagovoru sv. Marka usmenom predajom kroz stoljeća prenose se legende. Kult sv. Marka u Hrvata potvrđuju i dvije katedrale te tridesetak crkava posvećenih tome svecu. Otok Mrkan ime baštini po sv. Marku evanđelistu. Mrkanski biskup, fra Nikola spominje se 1322. godine, a koji je 1326. kao trebinjski biskup administrirao na Mrkanu. Trebinjsko-mrkanska biskupija spominje se 1344. godine.

Uz blagdan sv. Marka u kršćanskoj kulturnoj baštini vezuju se procesije i blagoslovi polja, usjeva, vinograda. Taj vjerski obred ima i pučki panspermijski i apotropejski karakter. U nekim krajevima, primjerice u Imotskoj krajini, na blagdan sv. Marka po svršetku mise blagoslivljalo se cvijeće i trava. Travi su pridavana apotropejska svojstva te se davala stoci vjerujući da će tako biti zaštićena od bolesti, uroka i ugriza zmija. Drevni običaji u nekim mjestima reducirali su se i/ili modificirali, a u nekim, primjerice u Kostanju iščezli.

Premda Markovdan nije »zapovjedani« svetac toga dana se ne radi, a jedino se može pomagati sirotinji. U mnogim mjestima održavaju se pučka veselja. U Jardolu kod Viteza od davnina postoji križ posvećen ondašnjem težaku i sv. Mar-

\footnotetext{
${ }^{105}$ Vendi Bilandžić zapisala je 2012. godine, a kazala joj je Evelina Rusak, djev. Boden. Rođena je na sam Badnjak 1928. godine na otoku Pagu, kao najmlađe od šestero djece u obitelji. Kao malo dijete preselila se sa svojom obitelji u Zadar, gdje su ugodno i lijepo živjeli do Drugoga svjetskog rata. Nakon smrti oca i siromaštva izazvanog ratnim događanjima, braća i sestre odlaze u razne krajeve svijeta. Evelina je otišla u Kaliforniji, ali svoje podrijetlo nikad ne zaboravlja i s ponosom ističe da Hrvatsku u srcu nosi (FF ST, 2012, S).
} 
ku. Uz Markovo vežu se pučke divinacije i izreke. U hrvatskoj tradicijskoj kulturi krjesovi su se palili, uglavnom, u Badnje predvečerje, Silvestrovsku noć, na Uskrs, Sv. Jurja, na blagdan rođenja Ivana Krstitelja. Krjesovi su se, primjerice, u Dolu na Hvaru, palili i uoči blagdana sv. Marka. Sv. Marko opjevan je i u usmenim lirskim pjesmama. O kultu sv. Marka svjedoči i molitva na uskrsno jutro u kojoj se iskazuje sreća zbog Kristova uskrsnuća i mnogih čuda o kojima piše sveti Marko.

\section{Marko Dragić* \\ Saint Mark the Evangelist in Croats' Christian traditional cultural heritage} Summary

Saint Mark the Evangelist (Cyrene around 10 AD - Alexandria April $25^{\text {th }} 68$ $\mathrm{AD})$ was a member of the Jewish tribe o Levi. He is nephew of Saint Barnabas, close associate of Saint Paul and Peter to whom he was secretary. In the New Testament he is mentioned eight times and Mary mother of John called Mark is mentioned for the ninth time. The first Christian community in Jerusalem gathered in his mother Mary's home. According to some sources Jesus ate his last supper in Mark's mother Mary's house.

He is worshipped by: The Roman Catholic Church, The Orthodox Church, The Coptic Church, the eastern Catholic churches, the Lutheran Church. He is multiple patron. Worship of Saint Mark the evangelist in Croats' Christian traditional culture is reflected in legends; cathedrals and churches consecrated to that evangelist; toponyms; chrematonyms; processions and blessings of fields, crops, vineyards; folk celebrations (fairs); helping the poor; cult shrines; folk divinations and sayings; bonfires; oral lyrical poems; prayers.

The paper cites the results of field research conducted from the year 1997 until the year 2016. About fifty legends, prayers, customs, rituals, processions, divinations have been originally recorded among Croatian Catholics in Croatia, Bosnia and Herzegovina, Montenegro and Serbia.

The paper (re)constructs the life of Saint Mark the Evangelist on the basis of the New Testament, tales and legends. Further, the aim of the paper is to save from the oblivion the old legends, customs, rituals, processions, oral lyrical poems, prayers, divinations and to point out their social and aesthetic function using the multidisciplinary interpretation. Inductive-deductive method and methods of description, comparison, analysis and synthesis are used alongside the filed research work.

Key words: legends, customs, processions, divinations, oral lyrical poems.

(na engl. prev. Nikola Sunara)

\footnotetext{
* Marko Dragić, PhD, Full Professor, Head of the Department of Literature and Culture, Faculty of Philosophy, University of Split; Address: Sinjska 2, HR-21000 Split, Croatia; E-mail: mdragic@ffst.hr.
} 